\title{
Nitrogen turnover in fresh Douglas fir litter directly after additions of moisture and inorganic nitrogen
}

\author{
Klaasjan J. Raat • Albert Tietema • \\ Jacobus M. Verstraten
}

Received: 5 May 2009 / Accepted: 21 September 2009 /Published online: 17 October 2009

(C) The Author(s) 2009. This article is published with open access at Springerlink.com

\begin{abstract}
The effects of wetting and drying and inorganic nitrogen $(\mathrm{N})$ addition on carbon $(\mathrm{C})$ and $\mathrm{N}$ turnover in fresh Douglas fir litter (Speuld forest, the Netherlands) were investigated. Litter was incubated for 9 days in the laboratory, receiving different moisture and $\mathrm{N}$ addition treatments. Following the additions, a series of reactions were observed of which most notable were a rapid retention of added ammonium and nitrate $\left(\mathrm{NO}_{3}{ }^{-}\right)$and a sudden increase in $\mathrm{CO}_{2}$ respiration. For the rewetted-and-moist incubations, respiration levels remained elevated, $\mathrm{N}$ was net immobilized and nitrous oxide $\left(\mathrm{N}_{2} \mathrm{O}\right)$ production increased throughout the experiment. About $80 \%$ of the $\mathrm{NO}_{3}{ }^{-}$produced was lost again as $\mathrm{N}_{2} \mathrm{O}$. In the rewetted-and-dried incubations, respiration decreased during the drying phase; no clear patterns in $\mathrm{N}$ mineralization were detected; and $\mathrm{N}_{2} \mathrm{O}$ production remained at constant levels, but still resulted in gaseous loss for half of the $\mathrm{NO}_{3}{ }^{-}$net produced. The experiments thus revealed two important $\mathrm{NO}_{3}{ }^{-}$sinks
\end{abstract}

Responsible Editor: Per Ambus.

A. Tietema $(\bowtie) \cdot$ J. M. Verstraten

Institute for Biodiversity and Ecosystem Dynamics (IBED),

Universiteit van Amsterdam,

Nieuwe Achtergracht 166,

Amsterdam NL-1018WV, The Netherlands

e-mail: a.tietema@uva.nl

K. J. Raat

KWR Watercycle Research Institute,

PO Box 1072, Nieuwegein NL-3430BB, The Netherlands in LF1 litter, namely rapid retention of added $\mathrm{NO}_{3}{ }^{-}$ and gaseous loss as $\mathrm{N}_{2} \mathrm{O}$. The maximum $\mathrm{NO}_{3}{ }^{-}$loss via these sinks was estimated at $2 \mathrm{~kg}-\mathrm{N} \mathrm{ha}{ }^{-1} \mathrm{yr}^{-1}$, which is small compared to annual $\mathrm{NO}_{3}{ }^{-}$leaching at $90 \mathrm{~cm}$ soil depth $\left(31 \mathrm{~kg}-\mathrm{N} \mathrm{ha}{ }^{-1} \mathrm{yr}^{-1}\right)$.

Keywords Douglas fir · Litter · Drying and rewetting · Nitrogen transformations $\cdot$ Respiration $\cdot$ Nitrous oxide

\section{Introduction}

Forests in the Netherlands have experienced elevated atmospheric $\mathrm{N}$ inputs for nearly 50 years now, and the growing concern about the effects of these increased inputs on forest ecosystem functioning has initiated intensive scientific research in the field of $\mathrm{N}$ cycling since the early 1980s. In general, the studies undertaken have a temporal resolution of weeks to years, either by direct choice (for example to elucidate longterm changes in the functioning of forest ecosystems like Koopmans et al. 1996), or because changes in $\mathrm{N}$ pool sizes are slow and require time to be measured (for example field incubations like in Tietema 1993). Microbial processes, however, are highly dynamical and respond rapidly to changes in conditions in the forest soil, like temperature, moisture and nutrient inputs. Consequently, while standard low-resolution $\mathrm{N}$ research is important and necessary, it may overlook mechanisms and processes operating at a shorter time scale. 
In recent years, there has been a growing interest in short-term $\mathrm{N}$ dynamics, especially in reaction to moderate treatments of the soil like recursive freezing and thawing, wetting and drying, or fertilizer additions (Kuzyakov et al. 2000). An important driver for this research is climate change that will likely have implications for nutrient availability and leaching losses in soils (Borken and Matzner 2008). For example, Pulleman and Tietema (1999) showed that in the Douglas fir forest of Speuld, the Netherlands, rewetting of dried litter could induce a large, temporary increase in microbial activity and a subsequent temporary net $\mathrm{N}$ mineralization flush. Litter from Harvard Forest in northeastern United States has been shown to rapidly immobilize added nitrate $\left(\mathrm{NO}_{3}{ }^{-}\right)$(Berntson and Aber 2000; Dail et al. 2001), even though this experimental forest had been subject to chronic $\mathrm{NO}_{3}{ }^{-}$additions for 11 years. Kuzyakov et al. (2000) summarize a number of possible reactions to inorganic-N additions, including increased $\mathrm{N}$ immobilization by microorganisms and acceleration of organic matter decomposition.

In an earlier study (Raat et al. 2002), it was shown that during a rain event not only the forest floor is rewetted, but that simultaneously a large pulse of inorganic-N is added via throughfall. Recorded $\mathrm{N}$ pulses were as high as $2.7 \mathrm{~kg}-\mathrm{N} \mathrm{ha}{ }^{-1}$, equaling about $6.5 \%$ of the yearly atmospheric $\mathrm{N}$ deposition. Pulleman and Tietema (1999) already emphasized the dynamical reaction of $\mathrm{N}$ transformations to rewetting of Speuld litter. Analogous, we hypothesize that inorganic-N addition may also enforce short-term changes in the turnover of $\mathrm{C}$ and $\mathrm{N}$ in Speuld litter, for example like those put forward by Berntson and Aber (2000) and Kuzyakov et al. (2000).

The aim of the current paper was to gain insight in the effects of simultaneous rewetting and throughfall $\mathrm{N}$ additions on the carbon $(\mathrm{C})$ and $\mathrm{N}$ turnover in a Douglas fir forest. Focus was on the top LF1 horizon of the forest floor as the first contact of throughfall water is within this horizon. Field moisture conditions just before and directly after a rain event were mimicked in a laboratory incubation experiment, while solutions containing $\mathrm{NH}_{4}{ }^{-}$and/or $\mathrm{NO}_{3}{ }^{-}$were added. Measurements were conducted on a high frequency basis, i.e. every one to 2 days, to capture possible dynamic responses of $\mathrm{C}$ and $\mathrm{N}$ turnover to the imposed treatments.

\section{Materials and methods}

Site description and sampling

The Speuld research site is a 2.5 ha Douglas fir (Pseudotsuga menziesii, Franco L.) forest stand, located in the centre of The Netherlands. The forest was planted in 1962, with an initial tree density of 780 trees $\mathrm{ha}^{-1}$, and was thinned in the winter of 19951996 leaving about two-thirds of the trees standing. Understorey vegetation was absent both before and after thinning. The forest floor has a thickness of about $6 \mathrm{~cm}$ (Schaap et al. 1997) and consists of a $4.5 \mathrm{~cm}$ thick F2 horizon, overlain by $1.5 \mathrm{~cm}$ of LF1 horizon; an $\mathrm{H}$ horizon is mostly absent. The humus form is classified as a Mormoder (Green et al. 1993). The soil is a well-drained Haplic Podzol (FAO 2006) with a groundwater level at $40 \mathrm{~m}$ depth throughout the year. Average precipitation is $834 \mathrm{~mm} \mathrm{yr}^{-1}$, while mean potential evapotranspiration is $712 \mathrm{~mm} \mathrm{yr}^{-1}$ (Tiktak and Bouten 1994). Mean January temperature is $1.5^{\circ} \mathrm{C}$; July temperature is $17.0^{\circ} \mathrm{C}$ (Bosveld et al. 1993). The forest is considered nitrogen saturated, as a result of nearly 50 years of elevated atmospheric $\mathrm{N}$ input (Koopmans et al. 1996; Van Breemen and Verstraten 1991). Nitrogen deposition in throughfall amounts to $42 \mathrm{~kg}-\mathrm{N} \mathrm{ha}^{-1} \mathrm{yr}^{-1}$, mainly in the form of $\mathrm{NH}_{4}^{+}$. Nitrogen leaching at $90 \mathrm{~cm}$ soil depth is $31 \mathrm{~kg}-\mathrm{N}$ ha ${ }^{-1} \mathrm{yr}^{-1}$, mainly as $\mathrm{NO}_{3}{ }^{-}$. Nitrogen transformations occur mainly in the forest floor (Tietema et al. 1993).

The Speuld Douglas fir forest has been subject of intensive research since the mid-1980s. Relevant work with respect to the current study include investigations of $\mathrm{N}$ mineralization and nitrification (Tietema et al. 1993; Tietema and Wessel 1992), anoxic micro-sites in litter in relation to $\mathrm{N}_{2} \mathrm{O}$ production (Van der Lee et al. 1999), C and N transformations during drying and rewetting (Pulleman and Tietema 1999) and forest floor hydrology (Schaap et al. 1997).

A composite litter sample (LF1 horizon) was obtained in late-autumn by sampling the top $1.5 \mathrm{~cm}$ of the forest floor in three $1 \mathrm{~m}^{2}$ patches, randomly chosen across the forest stand. Cones, branches and roots were removed immediately after sampling. The remaining material was sieved through a $10 \mathrm{~mm}$ nylon mesh, air-dried (gravimetric water content $w=$ $115 \%)$ and stored dark and cool $\left(2^{\circ} \mathrm{C}\right)$ until the 
beginning of the experiment. Some chemical characteristics of the litter are given in Table 1 .

Experimental set up

Polypropylene jars were filled with the equivalent of $6.0 \mathrm{~g}$ dry litter $(w=115 \%)$ and stored in a climate chamber 2 days prior to the start of the experiment, in order to enable the microbial community to adapt to the incubation temperature of $20^{\circ} \mathrm{C}$. Jars were divided into eight series receiving different treatments (Table 2). These treatments involved rewetted-and-continuously-moist (MO) and rewettedand-dried (WD) incubations, and additions of throughfall solutions containing $\mathrm{NH}_{4}^{+}, \mathrm{NO}_{3}^{-}$, both $\mathrm{NH}_{4}^{+}$and $\mathrm{NO}_{3}{ }^{-}$, or no nitrogen at all. Parallel to the samples kept in polypropylene jars we had 8 series in glass jars. These series received the same moisture and $\mathrm{N}$ addition treatments and were used to determine $\mathrm{CO}_{2}$ and $\mathrm{N}_{2} \mathrm{O}$ production.

The moisture dynamics imposed to the WD treatments were copied from dynamics in forest floor water content of the F2 horizon of the Speuld Forest as described by Schaap et al. (1997). A single summer rain shower was modeled followed by a 9 day drying period. Drying in our experiment $(w=50 \%$ after 9 days), however, was somewhat more severe than that observed by Schaap et al. (1997), since we believe that drying is more severe in top LF1 horizon than in the F2 horizon that they studied.

Amounts of $\mathrm{NH}_{4}{ }^{+}$and/or $\mathrm{NO}_{3}{ }^{-}$added (Table 2) were calculated from the amounts of nitrogen added to the forest floor during a rain event $\left(2.7 \mathrm{~kg}-\mathrm{N} \mathrm{ha}{ }^{-1}\right.$; Hansen et al. 1994; Raat et al. 2002), the molar ratio of $\mathrm{NH}_{4}{ }^{+}: \mathrm{NO}_{3}{ }^{-}$in throughfall $(2.7: 1$; Draaijers et al. 1998) and the total dry mass of the forest floor (3.2 $\mathrm{kg} \mathrm{m}^{-2}$; Wessel and Tietema 1995). In this

Table 1 Characteristics of sampled fresh, LF1 horizon Douglas fir litter

\begin{tabular}{ll}
\hline Horizon & LF1 \\
\hline Thickness & $1.5 \mathrm{~cm}$ \\
$\mathrm{pH}(1.0 \mathrm{M} \mathrm{KCl})$ & 4.3 \\
$\mathrm{pH}\left(\mathrm{H}_{2} \mathrm{O}\right)$ & 5.1 \\
$\mathrm{C}: \mathrm{N}$ & $24.7 \mathrm{~g} \mathrm{~g}^{-1}$ \\
$\mathrm{NH}_{4}{ }^{+}(\mathrm{KCl}$-extractable $)$ & $33.3 \mathrm{mmol}^{-\mathrm{N} \mathrm{kg}}{ }^{-1}$ \\
$\mathrm{NO}_{3}{ }^{-}(\mathrm{KCl}$-extractable $)$ & $0.45 \mathrm{mmol}^{-\mathrm{N} \mathrm{kg}^{-1}}$ \\
\hline
\end{tabular}

calculation we assumed that throughfall was distributed evenly over the top half of the forest floor. In addition to nitrogen species, all added solutions contained a combination of other ions to mimic throughfall of the Speuld forest (Draaijers et al. 1998). These other ions were also added to the control series that lacked $\mathrm{N}$ additions. Added concentrations were $1.22,0.04,0.20,0.16$ and $0.47 \mathrm{mmol} \mathrm{kg}^{-1}$ dry litter for $\mathrm{SO}_{4}{ }^{2-}$, ortho-P, $\mathrm{Ca}^{2+}, \mathrm{Mg}^{2+}$ and $\mathrm{K}^{+}$, respectively. $\mathrm{Na}^{+}$replaced $\mathrm{NH}_{4}^{+}$for treatments where no $\mathrm{NH}_{4}^{+}$was added, $\mathrm{Cl}^{-}$replaced $\mathrm{NO}_{3}{ }^{-}$. Added concentrations of $\mathrm{Na}^{+}$thus varied between 0 and 2.91, added $\mathrm{Cl}^{-}$varied between 0.61 and $1.70 \mathrm{mmol} \mathrm{kg}{ }^{-1}$ dry litter.

The experiment was started ( $t=0$ days) by dripping concentrated throughfall solutions on the incubated litter using a 1,000 $\mu$ l pipette. Subsequently, using a conventional plant sprayer, demineralized water was sprayed on the litter in order to spread the added substances equally over the litter and to reach a gravimetric water content of $275 \%$. The MO series were kept in semi-open containers with wet towels. The wet towels created a damp atmosphere that successfully prevented drying of the litter, while the semi-open container still enabled aeration. The WD series were left completely open for the first 3 days to induce air-drying. At $t=3.0$ days, these series were placed in semi-open containers (but without the wet towels) to somewhat slow down drying. Figure 1 shows the moisture conditions for $\mathrm{MO}$ and $\mathrm{WD}$ incubations during the course of the experiment.

To characterize the litter's initial conditions, at $t=$ 0.0 days, five samples that had not received any treatment since incubation 2 days prior, were analyzed for $\mathrm{NH}_{4}^{+}, \mathrm{NO}_{2}^{-}$and $\mathrm{NO}_{3}^{-}$. First regular sampling started at $t=0.13$ days, when three randomly chosen samples $(n=3)$ were taken from every serie and destructively analyzed for $\mathrm{NH}_{4}^{+}, \mathrm{NO}_{2}^{-}$and $\mathrm{NO}_{3}{ }^{-}$. $\mathrm{CO}_{2}$ and $\mathrm{N}_{2} \mathrm{O}$ production were measured from samples stored in the glass jars $(n=3)$, upon which these were returned to the climate chamber. This sampling procedure was repeated at $t=1.0,2.0,3.0$, 5.0, 7.0 and 9.0 days, but $\mathrm{CO}_{2}$ respiration and $\mathrm{N}_{2} \mathrm{O}$ production were not determined on $t=5.0$ days. Concentrations of $\mathrm{NH}_{4}^{+}, \mathrm{NO}_{2}^{-}$and $\mathrm{NO}_{3}{ }^{-}$were determined colorimetrically in $1.0 \mathrm{M} \mathrm{KCl}$ extracts (soil:solution=1:30) on a Skalar continuous flow auto-analyzer. $\mathrm{NO}_{2}{ }^{-}$concentrations were always under the detection limit, and so $\mathrm{NO}_{2}^{-}$was not used in any further calculations or analysis. $\mathrm{CO}_{2}$ and $\mathrm{N}_{2} \mathrm{O}$ 
Table 2 Experimental setup. Short names for treatments (as used in the text), imposed moisture conditions and added $\mathrm{NH}_{4}{ }^{+}$and $\mathrm{NO}_{3}{ }^{-}$ loads

\begin{tabular}{|c|c|c|c|}
\hline ShortName & Moisture condition & added $\mathrm{NH}_{4}^{+}\left[\right.$mmol-N kg ${ }^{-1}$ dry $]$ & added $\mathrm{NO}_{3}{ }^{-}\left[\mathrm{mmol}-\mathrm{N} \mathrm{kg}^{-1}\right.$ dry $]$ \\
\hline MO-noN & Continuously moist & 0.0 & 0.0 \\
\hline $\mathrm{MO}-\mathrm{NH}_{4} \mathrm{NO}_{3}$ & Continuously moist & 2.9 & 1.1 \\
\hline $\mathrm{MO}-\mathrm{NH}_{4}$ & Continuously moist & 2.9 & 0.0 \\
\hline $\mathrm{MO}-\mathrm{NO}_{3}$ & Continuously moist & 0.0 & 1.1 \\
\hline WD-noN & Rewetted and dried & 0.0 & 0.0 \\
\hline $\mathrm{WD}-\mathrm{NH}_{4} \mathrm{NO}_{3}$ & Rewetted and dried & 2.9 & 1.1 \\
\hline WD-NH ${ }_{4}$ & Rewetted and dried & 2.9 & 0.0 \\
\hline $\mathrm{WD}-\mathrm{NO}_{3}$ & Rewetted and dried & 0.0 & 1.1 \\
\hline
\end{tabular}

production were determined as headspace accumulation of both gasses after airtight sealing of the glass jars. $\mathrm{CO}_{2}$ was measured on a Carlo Erba GC equipped with a thermal conductivity detector, $\mathrm{N}_{2} \mathrm{O}$ on a Varian 3,600 GC equipped with an electron capture detector.

Throughout this paper, concentrations and rates are expressed per kilogram dry weight litter. Time $(t)$ is expressed in days since the addition of the throughfall solutions. $\mathrm{N}$ fluxes and rates were determined for 7 time intervals, which are referred to by Roman numbers $i$ to vii (Fig. 1).

\section{Calculation of $\mathrm{N}$ fluxes and statistics}

Cumulative $\mathrm{N}_{2} \mathrm{O}$ production was estimated by integrating $\mathrm{N}_{2} \mathrm{O}$ production rate over time. Net $\mathrm{N}$ mineralization rates were estimated from the change in total inorganic-N between two sampling dates. Net nitrification rates were estimated from the change in $\mathrm{NO}_{3}{ }^{-}$. Estimates of both net $\mathrm{N}$ mineralization and net nitrification were corrected for the loss of $\mathrm{NO}_{3}{ }^{-}$as $\mathrm{N}_{2} \mathrm{O}$ using the cumulative $\mathrm{N}_{2} \mathrm{O}$ production. In addition, estimates of net $\mathrm{N}$ mineralization and net nitrification between $t=0.0$ and $t=0.13$ (time interval $i$ ) were corrected for the $\mathrm{NH}_{4}{ }^{+}$and/or $\mathrm{NO}_{3}{ }^{-}$added. The Student's $T$-test was used to compare means. Differences at the $p=0.05$ level were considered significant.

\section{Results}

$\mathrm{C}$ and $\mathrm{N}$ fluxes directly after remoistening and $\mathrm{N}$ additions (time interval $\mathrm{i}$ )

As first regular sampling took place only $3 \mathrm{~h}(t=0.13)$ after the additions, the WD series had not yet lost substantial amounts of water, and moisture contents were the same $(w=275 \%)$ for both $\mathrm{MO}$ and WD series. As such, at this sampling time, both series are treated as one $(n=6)$, and the four different $\mathrm{N}$ addition treatments are referred to as T-noN, T- $\mathrm{NH}_{4} \mathrm{NO}_{3}, \mathrm{~T}$ $\mathrm{NH}_{4}$ and $\mathrm{T}-\mathrm{NO}_{3}$, respectively.

Even though breakdown of fresh litter is often thought to be $\mathrm{N}$ limited, prior to the start of the experiments $\mathrm{KCl}$-extractable $\mathrm{NH}_{4}{ }^{+}$concentrations were already high in the LF1 material. Initial $\mathrm{NH}_{4}{ }^{+}$

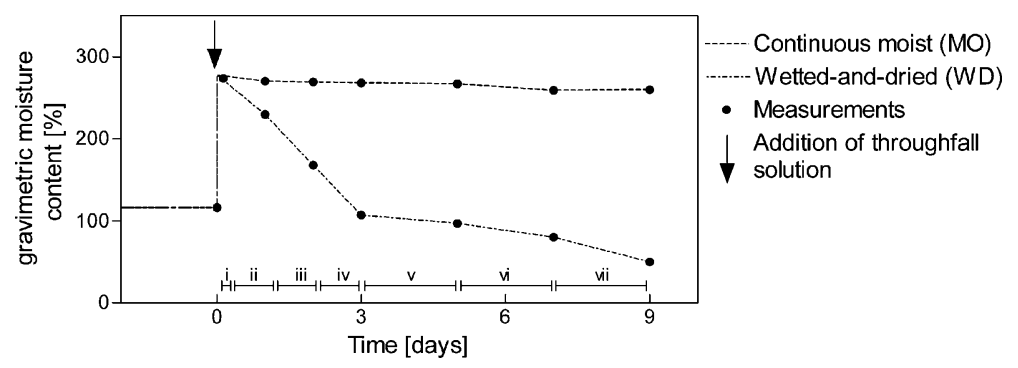

Fig. 1 Gravimetric water content [\%] for moist $(M O)$ and rewetted-and-dried $(W D)$ incubations. Arrow marks time of moisture and N additions, dots mark time of sampling. Brackets and roman numbers mark time intervals over which net $\mathrm{N}$ fluxes were calculated 
concentrations averaged $33.3 \mathrm{mmol}-\mathrm{N} \mathrm{kg}^{-1}$ (Table 1), implying that $\mathrm{NH}_{4}^{+}$added in the $\mathrm{T}-\mathrm{NH}_{4} \mathrm{NO}_{3}$ and $\mathrm{T}^{-\mathrm{NH}_{4}}$ treatments $(2.9$ mmol-N) could increase the $\mathrm{NH}_{4}{ }^{+}$concentration with a potential $9 \%$. Even though amounts of $\mathrm{NO}_{3}^{-}$added $\left(1.1 \mathrm{mmol}-\mathrm{N} \mathrm{kg}^{-1}\right.$, T- $\mathrm{NH}_{4} \mathrm{NO}_{3}$ and $\mathrm{T}-\mathrm{NO}_{3}$ ) were about one-third of $\mathrm{NH}_{4}{ }^{+}$ added, due to the low initial $\mathrm{KCl}$-extractable $\mathrm{NO}_{3}{ }^{-}$ concentrations (0.45 mmol-N kg ${ }^{-1}$; Table 1$), \mathrm{NO}_{3}{ }^{-}$ additions potentially more than tripled $\mathrm{NO}_{3}{ }^{-}$availability. Total inorganic- $\mathrm{N}$ additions measured 12,

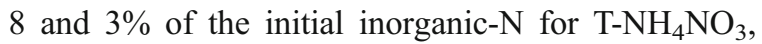
$\mathrm{T}-\mathrm{NH}_{4}$ and $\mathrm{T}-\mathrm{NO}_{3}$, respectively.

Upon wetting and $\mathrm{N}$ additions, a fast response of respiration and $\mathrm{N}$ fluxes was observed. Average $\mathrm{CO}_{2}$ respiration rate almost doubled from 139 mmol-C $\mathrm{kg}^{-1}$ day $^{-1} 1$ day prior to the start of the experiment $(w=115 \%)$ to 254 mmol-C $\mathrm{kg}^{-1}$ day $^{-1} 3 \mathrm{~h}$ after rewetting the litter to $w=275 \%(t=0.13$; Fig. 2$)$. No differences in respiration rates were observed between the different $\mathrm{N}$ treatments. For T- $\mathrm{NH}_{4} \mathrm{NO}_{3}$ and $\mathrm{T}-\mathrm{NH}_{4}$, the elevated respiration was accompanied by a large net $\mathrm{N}$ immobilization (retention, Fig. 3) of
23.0 and 8.2 mmol- $\mathrm{N} \mathrm{kg}^{-1} \mathrm{day}^{-1}$, respectively. Recorded net $\mathrm{N}$ immobilization rates for T-noN and $\mathrm{T}^{-\mathrm{NO}_{3}}$ were 4.9 and $1.2 \mathrm{mmol}-\mathrm{N} \mathrm{kg}{ }^{-1}$ day $^{-1}$, respectively, but these rates did not significantly deviate from $0 \quad(p=0.05)$. Net nitrification rates differed considerably between treatments that had received $\mathrm{NO}_{3}{ }^{-}$and those that had not. Whereas TnoN and $\mathrm{T}_{-} \mathrm{NH}_{4}$ showed a small net nitrification, T$\mathrm{NH}_{4} \mathrm{NO}_{3}$ and $\mathrm{T}-\mathrm{NO}_{3}$ showed a relatively large net $\mathrm{NO}_{3}{ }^{-}$retention. Recorded net $\mathrm{NO}_{3}{ }^{-}$retention rates amounted to an average of 1.6 mmol- $\mathrm{N} \mathrm{kg}^{-1}$ day $^{-1}$ for both treatments, implying that within $3 \mathrm{~h}$ after the additions about $18 \%$ of the added $\mathrm{NO}_{3}{ }^{-}$was lost. Note that $\mathrm{NO}_{3}^{-}$lost as $\mathrm{N}_{2} \mathrm{O}$ did not contribute to this net $\mathrm{NO}_{3}{ }^{-}$retention as $\mathrm{N}_{2} \mathrm{O}$ production was taken into account in the calculation of the net nitrification rates.

Continuously moist incubations two and more days after rewetting and $\mathrm{N}$ addition

Even though over the course of the experiment moisture contents did not change for the MO
Fig. $2 \mathrm{CO}_{2}$ respiration rate for a moist $(M O)$ and $\mathbf{b}$ rewetted-and-dried (WD) incubations. Brackets denote standard deviation. Horizontal brackets and roman numbers mark time intervals over which net $\mathrm{N}$ fluxes were calculated

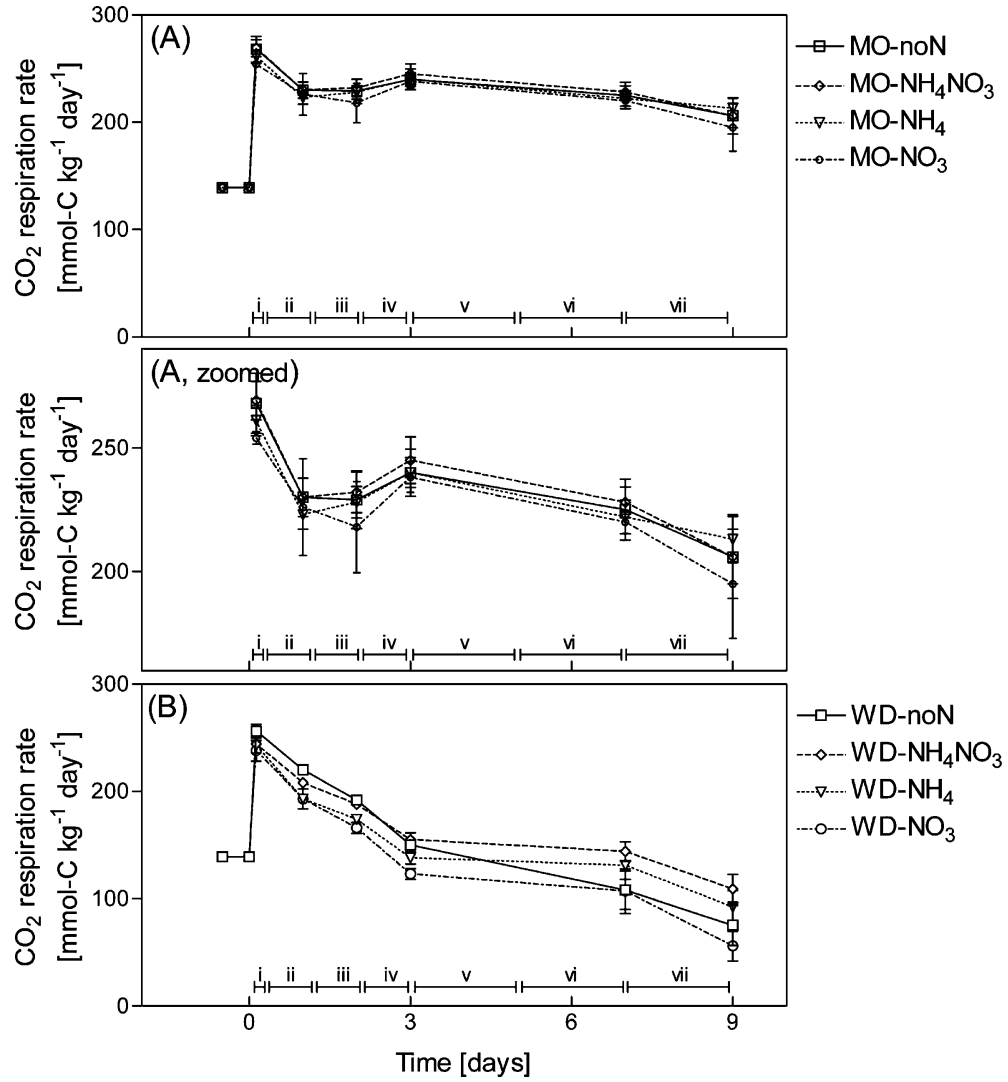


Fig. 3 Net $\mathrm{N}$ mineralisation $\mathbf{a}$ and net nitrification $\mathbf{b}$ rates of continuously moist incubations $(M O)$. Roman numbers refer to time intervals as in Fig. 1 and Table 3. Net rates that do not significantly deviate from 0 are marked with "o" $(p=0.05)$
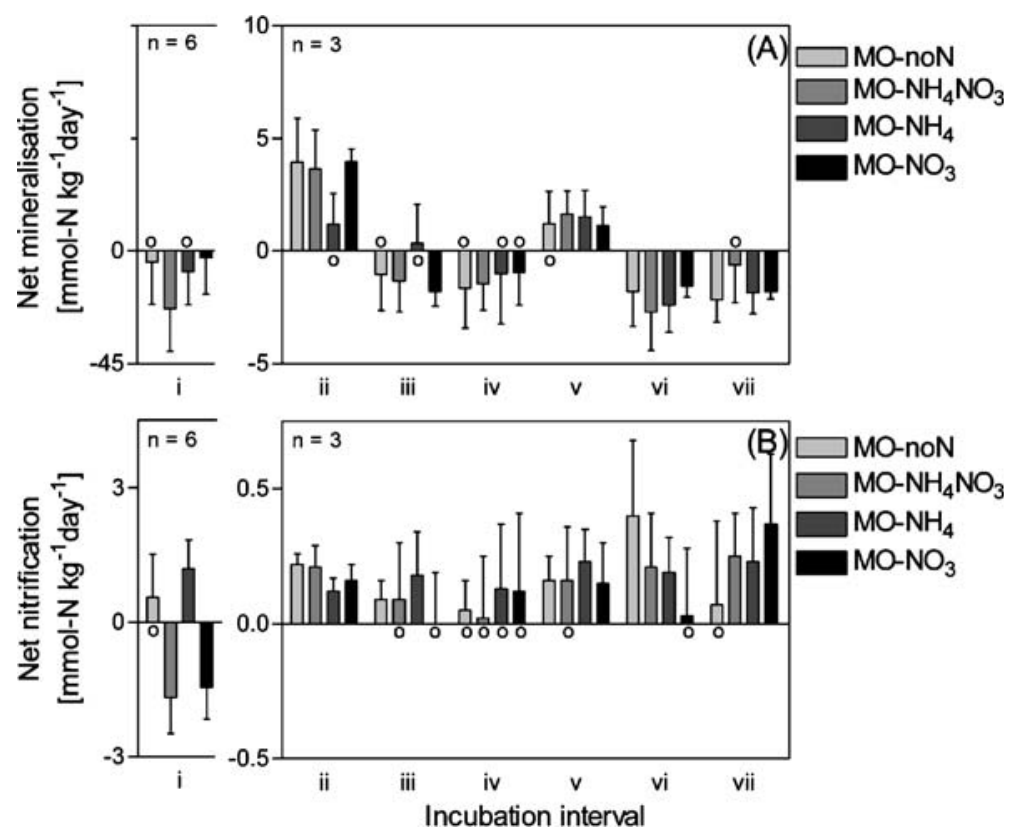

incubations, $\mathrm{CO}_{2}$ respiration rate decreased from an average of 254 mmol-C $\mathrm{kg}^{-1} \mathrm{day}^{-1}$ at $t=0.13$ to 227 mmol-C kg${ }^{-1}$ day $^{-1}$ at $t=1.0$ (Fig. 2a). No clear difference in respiration rates was observed between the different treatments. Parallel to this decrease in respiration, all MO incubations showed a net $\mathrm{N}$ mineralization between $t=0.13$ and 1.0 (time interval ii). Net mineralization rates were between 3.6 and 4.0 mmol-N kg${ }^{-1}$ day $^{-1}$ for MO-noN, MO- $\mathrm{NH}_{4} \mathrm{NO}_{3}$ and $\mathrm{MO}-\mathrm{NO}_{3}$, and were $1.2 \mathrm{mmol}-\mathrm{N} \mathrm{kg}^{-1}$ day $^{-1}$ for MO-NH $\mathrm{N}_{4}$ (Fig. 3a). Note that this latter rate did not significantly deviate from $0(p=0.05)$.

Between $t=1.0$ and 3.0 (ii), the average $\mathrm{CO}_{2}$ respiration rate somewhat increased again to 241 mmol-C kg-1 day $^{-1}$, after which it decreased to 224 and 205 mmol-C kg ${ }^{-1}$ day $^{-1}$ at $t=7.0$ and 9.0 (Fig. 2a). From $t=1.0$ to 9.0 , all treatments showed a net $\mathrm{N}$ immobilization, except between $t=3.0$ and 5.0 (v) and a small, but insignificant, net $\mathrm{N}$ mineralization for $\mathrm{MO}-\mathrm{NH}_{4}$ between $t=1.0$ and 2.0 (iii). When respiration rates at $t=5.0$, which were not determined, were in between rates measured at $t=3.0$ and $t=7.0$, i.e. when respiration rates decreased steadily after $t=3.0$, the temporal net $\mathrm{N}$ mineralization recorded between $t=3.0$ and $5.0(v)$ corresponded with a decrease in $\mathrm{CO}_{2}$ respiration following a temporal respiration increase. A similar relation between $\mathrm{N}$ mineralization and $\mathrm{CO}_{2}$ respiration was already observed between $t=0.13$ and 1.0 (ii). Effectively, over the total 9 days of incubation, all rewetted-andmoist incubations showed a net $\mathrm{N}$ immobilization (Table 3), which was highest for MO-noN and MO$\mathrm{NH}_{4}$ (both around 6 mmol- $\mathrm{N} \mathrm{kg}^{-1}$ ), intermediate for MO- $\mathrm{NH}_{4} \mathrm{NO}_{3}\left(5.2 \mathrm{mmol}-\mathrm{N} \mathrm{kg}^{-1}\right)$ and lowest for MO$\mathrm{NO}_{3}$ (4.1 mmol- $\mathrm{N} \mathrm{kg}^{-1}$ ), although differences between treatments were not significant $(p=0.05)$.

From $t=0.13$ until the end of the experiment all treatments showed a net production of $\mathrm{NO}_{3}{ }^{-}$(Fig. 3b). From day-to-day differences in net nitrification rates were observed between the treatments, but over the total period of $t=0.13$ to 9.0 no significant differences in cumulative net nitrification were detected. Cumulative net nitrification in that period ranged from 1.4 to $1.7 \mathrm{mmol}-\mathrm{N} \mathrm{kg}^{-1}$. At $t=0.13, \mathrm{~N}_{2} \mathrm{O}$ production measured about 0.08 mmol- $\mathrm{N} \mathrm{kg}^{-1}$ day ${ }^{-1}$, after which production rates steadily increased to between 0.17 and 0.25 mmol- $\mathrm{N} \mathrm{kg}^{-1} \mathrm{day}^{-1}$ at $t=9.0$ (Fig. 4a). This increase was faster for the $\mathrm{NO}_{3}{ }^{-}$receiving treatments $\left(\mathrm{MO}-\mathrm{NH}_{4} \mathrm{NO}_{3}\right.$ and $\mathrm{MO}-\mathrm{NO}_{3}$ ) with significantly higher $\mathrm{N}_{2} \mathrm{O}$ production rates $\left(0.19 \mathrm{mmol}-\mathrm{N} \mathrm{kg}^{-1}\right.$ day $\left.^{-1}\right)$ at $t=3.0$ than MO-noN and $\mathrm{MO}-\mathrm{NH}_{4}(0.15 \mathrm{mmol}-\mathrm{N}$ $\mathrm{kg}^{-1}$ day $^{-1}$ ). $\mathrm{N}_{2} \mathrm{O}$ production rates remained significantly higher at $t=7.0$ and 9.0 for $\mathrm{MO}-\mathrm{NH}_{4} \mathrm{NO}_{3}$, but for $\mathrm{MO}-\mathrm{NO}_{3}$ production rates were in the same order as those observed for MO-noN and $\mathrm{MO}-\mathrm{NH}_{4}$. Cumulative production of $\mathrm{N}_{2} \mathrm{O}$, determined over the total 
Table 3 Inorganic- $\mathrm{N}\left(\mathrm{NH}_{4}{ }^{+}+\mathrm{NO}_{3}{ }^{-}\right)$and $\mathrm{NO}_{3}{ }^{-}$concentrations at $t=9.0$ days, and net $\mathrm{N}$ mineralisation, net nitrification, $\mathrm{N}_{2} \mathrm{O}$ production and ratio of $\mathrm{N}_{2} \mathrm{O}$ production-to-net nitrification between $t=0.0$ and 9.0 days. Concentrations in mmol- $\mathrm{N} \mathrm{kg}^{-1}$. Fluxes in mmol-N kg ${ }^{-1}(9 \text { days })^{-1}$

\begin{tabular}{lllllll}
\hline Treatment & $\mathrm{NH}_{4}{ }^{+}+\mathrm{NO}_{3}{ }^{-}$ & $\mathrm{NO}_{3}{ }^{-}$ & net N mineralisation & net nitrification & $\mathrm{N}_{2} \mathrm{O}$ production & molar ratio $\mathrm{N}_{2} \mathrm{O}$ :net nitrification \\
\hline MO-noN & $26.4(1.3)$ & $0.71(0.24)$ & $-6.0(2.1)$ & $1.60(0.30)$ & $1.34(0.16)$ & 0.84 \\
MO-NH4NO3 & $30.9(1.8)$ & $1.13(0.26)$ & $-5.2(2.4)$ & $1.28(0.30)$ & $1.69(0.14)$ & 1.32 \\
MO-NH4 & $29.1(0.0)$ & $0.88(0.35)$ & $-6.2(1.7)$ & $1.86(0.35)$ & $1.43(0.01)$ & 0.77 \\
MO-NO3 & $29.3(0.6)$ & $1.17(0.23)$ & $-4.1(1.8)$ & $1.14(0.25)$ & $1.51(0.07)$ & 1.32 \\
WD-noN & $30.4(2.1)$ & $1.14(0.35)$ & $-3.0(2.7)$ & $1.14(0.37)$ & $0.45(0.09)$ & 0.39 \\
WD-NH4NO3 & $35.0(2.7)$ & $1.65(0.16)$ & $-2.2(3.2)$ & $0.69(0.19)$ & $0.58(0.07)$ & 0.84 \\
WD-NH4 & $34.9(1.0)$ & $1.26(0.22)$ & $-1.3(2.0)$ & $1.36(0.26)$ & $0.54(0.12)$ & 0.40 \\
WD-NO3 & $33.2(8.3)$ & $1.84(0.92)$ & $-1.2(8.5)$ & $0.75(0.92)$ & $0.45(0.03)$ & 0.60 \\
\hline
\end{tabular}

period of incubation, increased following $\mathrm{MO}-\mathrm{noN} \approx$ MO-NH $\mathrm{NH}_{4}<\mathrm{MO}-\mathrm{NO}_{3}<\mathrm{MO}-\mathrm{NH}_{4} \mathrm{NO}_{3}$ (Table 3).

For MO-noN and $\mathrm{MO}-\mathrm{NH}_{4}$, about $80 \%$ of the $\mathrm{NO}_{3}{ }^{-}$net produced by nitrification was lost again from the litter as $\mathrm{N}_{2} \mathrm{O}$ (Table 3). For $\mathrm{MO}-\mathrm{NH}_{4} \mathrm{NO}_{3}$ and $\mathrm{MO}-\mathrm{NO}_{3}, \mathrm{~N}_{2} \mathrm{O}$ production even exceeded net nitrification. In terms of net $\mathrm{NO}_{3}^{-}$loss or gain, exclusive of the additions, over the course of the experiment $\mathrm{MO}-\mathrm{noN}$ and $\mathrm{MO}-\mathrm{NH}_{4}$ gained about 0.3 to 0.4 mmol- $\mathrm{N} \mathrm{kg}^{-1}$ of $\mathrm{NO}_{3}{ }^{-}$, while $\mathrm{MO}-\mathrm{NH}_{4} \mathrm{NO}_{3}$ and $\mathrm{MO}-\mathrm{NO}_{3}$ lost about $0.4 \mathrm{mmol}-\mathrm{N} \mathrm{kg}^{-1}$. Thus, whereas at $t=0.13 \mathrm{NO}_{3}{ }^{-}$concentrations were almost three-fold higher for $\mathrm{NO}_{3}{ }^{-}$receiving treatments, this differences had largely disappeared at the end of the experiment (Table 3).

Rewetted-and-dried incubations two and more days after wetting and $\mathrm{N}$ addition

After the steep rise directly after the additions, $\mathrm{CO}_{2}$ respiration rates (Fig. 2b) steadily decreased with decreasing moisture content. A clear correlation between respiration rate and moisture content was observed, with $r^{2}$ ranging between 0.94 and 0.99 for linear regression models of moisture vs. respiration. Cumulative $\mathrm{CO}_{2}$ respiration, determined over the
Fig. $4 \mathrm{~N}_{2} \mathrm{O}$ production rates for a continuously moist $(M O)$ and $\mathbf{b}$ rewettedand-dried $(W D)$ incubations. Brackets denote standard deviation. Horizontal brackets and roman numbers mark time intervals over which net $\mathrm{N}$ fluxes were calculated

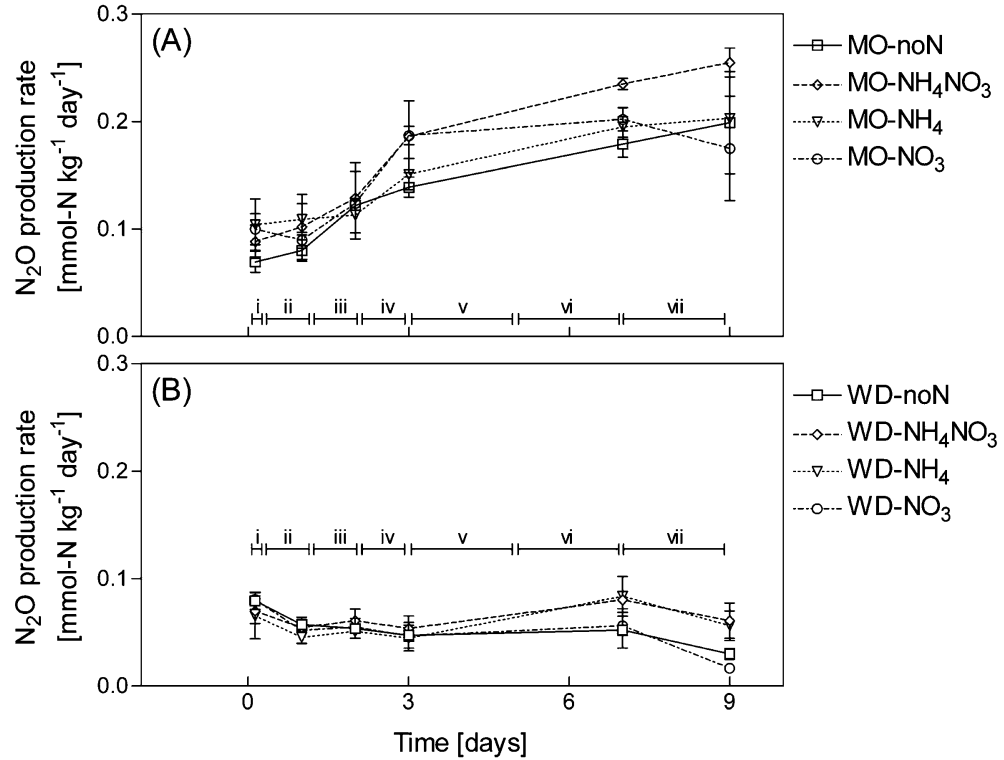


total period of incubation, was much smaller for the WD treatments $\left(1,300 \mathrm{mmol}-\mathrm{C} \mathrm{kg}^{-1}\right)$ than for the MO treatments $\left(2,050 \mathrm{mmol}-\mathrm{C} \mathrm{kg}^{-1}\right)$. At and before $t=3.0$, respiration rates were highest for WD-noN and $\mathrm{WD}-\mathrm{NH}_{4} \mathrm{NO}_{3}$. After $t=3.0$, rates declined more strongly for $\mathrm{WD}$-noN, resulting in a sequence in respiration rate at $t=9.0$ following $\mathrm{WD}-\mathrm{NO}_{3} \approx \mathrm{WD}$ noN $\leq$ WD-NH $\mathrm{NH}_{4} \approx \mathrm{WD}-\mathrm{NH}_{4} \mathrm{NO}_{3}$. Cumulative $\mathrm{CO}_{2}$ respiration estimated over the total period of incubation increased following WD- $\mathrm{NO}_{3}<\mathrm{WD}-$ noN $\approx$ WD- $\mathrm{NH}_{4}<$ WD-NH $\mathrm{NO}_{3}$.

Similar to the MO incubations, $\mathrm{N}$ was net mineralized between $t=0.13$ and 1.0 (time interval $i i$, Fig. 5a). Subsequently, between $t=1.0$ and 9.0 , no clear patterns in net $\mathrm{N}$ mineralization could be detected, i.e. temporary and small net $\mathrm{N}$ mineralizations were alternated by small net $\mathrm{N}$ immobilizations. Effectively, over the 9 days of incubation, all treatments showed a small net $\mathrm{N}$ immobilization (between 1.2 and 3.0 mmol-N kg-1, Table 3), but this immobilization was significant only for WD-noN. At $t=9.0$, inorganic-N concentrations were at the same level as before the start of the experiment, that is between 30 and 35 mmol- $\mathrm{N} \mathrm{kg}^{-1}$.

From $t=0.13$ until the end of the experiment all treatments showed a net nitrification (Fig. 5b). Again, from day-to-day differences in net nitrification rates were observed between the different treatments, but no clear trend was noticed. In addition, many of the recorded nitrification rates were insignificant. Total net nitrification, measured cumulative between $t=$ 0.13 and 9.0, amounted between 0.8 and $1.2 \mathrm{mmol}-$ $\mathrm{N} \mathrm{kg}^{-1}$, with no significant difference between the treatments. This net nitrification was lower than for the MO treatments where, for the same period, net nitrification was between 1.4 and 1.7 mmol- $\mathrm{N} \mathrm{kg}^{-1}$.

Unlike the $\mathrm{MO}$ incubations, $\mathrm{N}_{2} \mathrm{O}$ production rates remained at a constant low level of 0.02 to 0.08 mmol-N kg${ }^{-1}$ day $^{-1}$ (Fig. 4b). Between $t=0.13$ and 3.0, production rates were the same for all treatments, but from $t=7.0$ to 9.0 rates for WD-noN and $\mathrm{WD}-\mathrm{NO}_{3}$ were significantly lower than for the other two treatments. This lower $\mathrm{N}_{2} \mathrm{O}$ production rate did not correspond with lower $\mathrm{NO}_{3}{ }^{-}$concentrations, but did coincide with a lower $\mathrm{CO}_{2}$ production rate for these two treatments. Over the total period of incubation, for all treatments net nitrification was larger than the cumulative $\mathrm{N}_{2} \mathrm{O}$ production (Table 3). Thus, all treatments showed a net increase in $\mathrm{NO}_{3}{ }^{-}$ concentration and despite lower total net nitrification this increase was larger than for the MO series. At $t=9.0$, average $\mathrm{NO}_{3}^{-}$concentrations for the $\mathrm{NO}_{3}$ receiving treatments were still 0.5 mmol- $\mathrm{N} \mathrm{kg}^{-1}$ higher than for the non-receiving treatments (Table 3), but due to high standard deviations for $\mathrm{WD}-\mathrm{NO}_{3}$, only differences between WD- $\mathrm{NH}_{4} \mathrm{NO}_{3}$ and WD-
Fig. 5 Net $\mathrm{N}$ mineralisation $\mathbf{a}$ and net nitrification $\mathbf{b}$ rates of rewetted-and-dried incubations $(W D)$. Roman numbers refer to time intervals as in Fig. 1 and Table 3. Net rates that do not significantly deviate from 0 are marked with "o" $(p=0.05)$

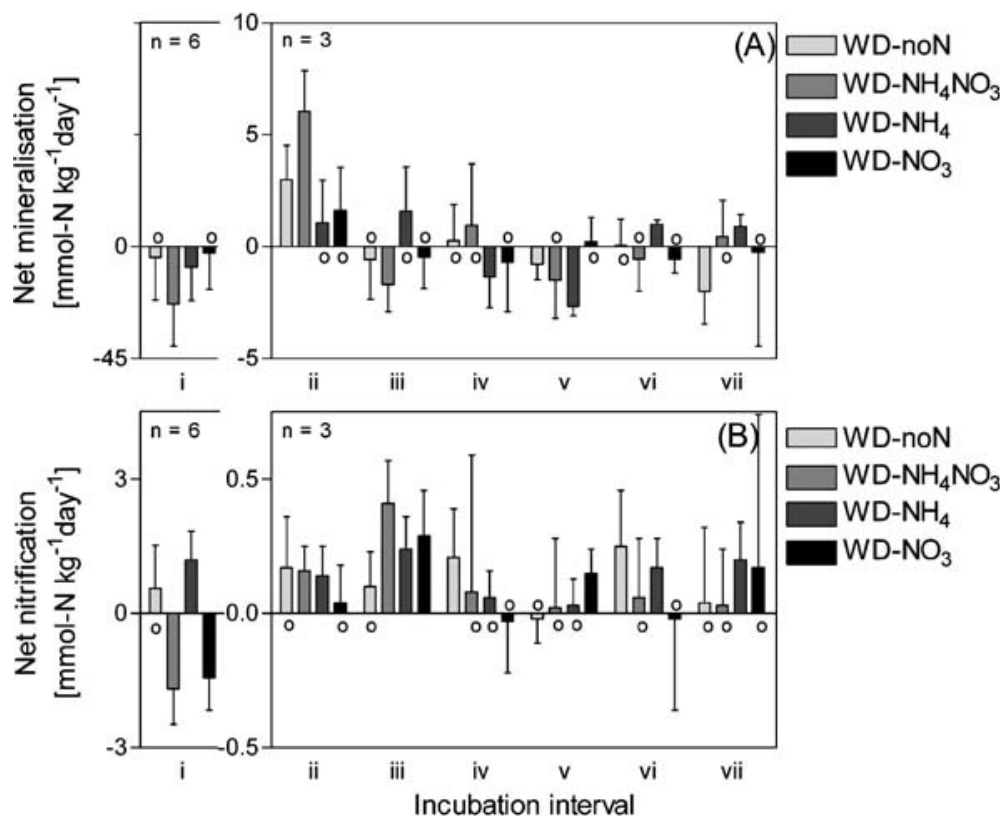


noN, and between WD- $\mathrm{NH}_{4} \mathrm{NO}_{3}$ and $\mathrm{WD}-\mathrm{NH}_{4}$ were significant.

\section{Discussion}

This discussion section is structured around four main topics. These are the observed rapid $\mathrm{N}$ retention directly after $\mathrm{N}$ additions, the linkage between $\mathrm{CO}_{2}$ respiration and net $\mathrm{N}$ mineralization, the potential of the fresh litter for $\mathrm{N}_{2} \mathrm{O}$ production, and, finally, the implications of $\mathrm{N}$ additions for $\mathrm{N}$ retention and loss at the Speuld forest.

\section{Rapid $\mathrm{N}$ retention directly after $\mathrm{N}$ additions}

A relatively large net $\mathrm{N}$ immobilization was observed in the first $3 \mathrm{~h}$ after the additions (time interval $i$ ) when $\mathrm{NH}_{4}{ }^{+}$had been added to the fresh litter. Similar, $\mathrm{NO}_{3}{ }^{-}$receiving samples showed a net retention of $\mathrm{NO}_{3}^{-}$, summing up to about $18 \%$ of the $\mathrm{NO}_{3}{ }^{-}$added.

Rapid immobilization of added $\mathrm{NO}_{3}^{-}$has been detected in other studies, even for forests that are subject to chronic $\mathrm{N}$ deposition (e.g., Berntson and Aber 2000; Dail et al. 2001; Fitzhugh et al. 2003). For mixed hardwood and pine stands in Northern America, Berntson and Aber (2000) reported as much as $34-62 \%$ of the added ${ }^{15} \mathrm{NO}_{3}^{-}$to be immobilized by the forest floor within 15-45 min after the additions. For a mixed hardwood stand of the same forest, Dail et al. (2001) found that between 30 and $60 \%$ of ${ }^{15} \mathrm{NO}_{3}{ }^{-}$added to forest floor material disappeared from the inorganic-N pool within $15 \mathrm{~min}$ after the additions. Of this immobilized ${ }^{15} \mathrm{NO}_{3}^{-}$, about $95 \%$ was recovered as DON and it was argued that an abiotic process was responsible for this $\mathrm{N}$ transformation (Dail et al. 2001). At present, there is much discussion about the true occurrence of abiotic $\mathrm{NO}_{3}$ incorporation in soils and reference is made to the debate between Colman and Davidson (Colman et al. 2007, 2008; Davidson et al. 2008).

It remains unclear what caused the rapid retention of the added $\mathrm{N}$ in our study, which was not designed to detect the exact pathways of the added N. The results do, however, show that rapid retention has place in fresh litter, and that this could be an important pathway for $\mathrm{NO}_{3}^{-}$retention in this $\mathrm{N}$ saturated Douglas fir forest.
Respiration and net $\mathrm{N}$ mineralization responses to wetting

The wetting of the litter at the start of the experiment resulted in a steep rise in $\mathrm{CO}_{2}$ respiration, indicating an increase in microbial activity and a probable higher microbial demand for $\mathrm{N}$ upon wetting. In the days following the additions, $\mathrm{CO}_{2}$ respiration and $\mathrm{N}$ mineralization seemed closely linked, with $\mathrm{N}$ being net mineralized when $\mathrm{CO}_{2}$ respiration rates (temporarily) decrease.

Almost immediate increase in respiration after rewetting has been recorded by others (e.g., Borken et al. 2003), though recovery of $\mathrm{CO}_{2}$ respiration to optimal levels may also take a few days (Muhr et al. 2008). Secondary peaks or oscillation periods of $\mathrm{CO}_{2}$ respiration, as observed for the MO incubations, have also been reported by Clein and Schimel (1994) for birch litter that was kept moist after an initial drying. They, similar to Lund and Goksøyr (1980), attributed this to species diversity within the microbial community, with some species reacting to wetting slower than others. The recorded temporal elevated $\mathrm{CO}_{2}$ respiration (period $i$ ) is well-known from the literature and is often referred to as the Birch-effect, after the pioneering work of Birch (1964). Several different processes may be responsible for this effect, as summarized by Muhr et al. (2008, p.726).

Our results contrast with the findings of Pulleman and Tietema (1999), who performed drying and wetting experiments with older (F2 horizon) litter from the same forest stand. They also observed a rapid increase in respiration rates upon rewetting, but in their experiment this coincided with a large, temporary net $\mathrm{N}$ mineralization flush rather than a net $\mathrm{N}$ immobilization. This different response to rewetting can be explained largely by the difference in magnitude of the drying prior to wetting in both experiments and differences in substrate quality and microbial community structures between both types of litter. The extreme drying treatment ( $w=10 \%$ prior to rewetting) in the experiment of Pulleman and Tietema (1999) generated easily decomposable (biomass and non-biomass derived) substrate, which before drying was not generally present in the litter. After wetting, gross mineralization increased rapidly, but increase in growth of the microbial community and subsequent gross immobilization was delayed as the microbial community had to adapt to the new, 
easily decomposable substrate. Thus, a net $\mathrm{N}$ mineralization flush was observed directly after the rewetting. In our experiment, in which actual field moisture conditions of the Speuld forest floor were more closely mimicked, drying prior to rewetting was not that severe $(w=115 \%)$ and probably did not have much effect on the substrate quality. In addition, our fresh litter already contained substantial amounts of easily decomposable organic matter, as shown by the relatively high respiration rates in our experiments. As such, after wetting, the microbial community did not have to adapt to the substrate and there was no delay in microbial growth after wetting.

Between $t=0.13$ and 1.0 , respiration rates somewhat decreased for MO and WD treatments. Likewise, for the MO incubations between $t=3.0$ and 5.0, respiration rates decreased after an increase in the days before. We hypothesize that the net $\mathrm{N}$ mineralization observed in these periods was due to ongoing activity of extracellular enzymes that were produced in surplus when the microbial community was still growing. Exoenzymes are produced by microorganisms to catalyze the breakdown of organic matter (Michel and Matzner 2003; Schimel and Weintraub 2003). Hence, there was a time lag between decrease in microbial demand (gross immobilization) and decrease in enzyme activity (gross mineralization), resulting in a temporary net $\mathrm{N}$ mineralization. During the drying phase of the WD treatments, respiration rates steadily decreased. Small and mostly insignificant net $\mathrm{N}$ immobilization was alternated with insignificant net $\mathrm{N}$ mineralization, indicating a tight balance between $\mathrm{N}$ immobilization and mineralization during this period of decreasing microbial activity.

$\mathrm{N}_{2} \mathrm{O}$ production potential in fresh litter

The relatively high, and at the end of the experiment still increasing $\mathrm{N}_{2} \mathrm{O}$ production in the MO incubations indicate that fresh litter from this forest has a high potential for $\mathrm{N}_{2} \mathrm{O}$ production. However, as shown by lower $\mathrm{N}_{2} \mathrm{O}$ production in the WD series, that more closely mimicked the actual moisture conditions in the Speuld litter, this potential is probably not fully exploited in the field. Still, even for the WD treatments, $\mathrm{N}_{2} \mathrm{O}$ production was relatively high compared to net nitrification, with approximately half of the net produced $\mathrm{NO}_{3}^{-}$being lost again as $\mathrm{N}_{2} \mathrm{O}$. In these calculations, it was assumed that none of the $\mathrm{N}_{2} \mathrm{O}$ produced was transformed into $\mathrm{N}_{2}\left(\mathrm{~N}_{2}: \mathrm{N}_{2} \mathrm{O}\right.$ production ratio of $0: 1)$. We realize that this assumption may be too strict, even though relative to $\mathrm{N}_{2} \mathrm{O}$, production of $\mathrm{N}_{2}$ is low under acidic conditions (Blackmer and Bremner 1978; Wolf and Brumme 2003). Using a higher $\mathrm{N}_{2}$-to- $\mathrm{N}_{2} \mathrm{O}$ production ratio in our calculations of gaseous loss of $\mathrm{NO}_{3}{ }^{-}$, however, would have only increased the amounts of $\mathrm{NO}_{3}{ }^{-}$lost from the system as $\mathrm{N}_{2}$ and $\mathrm{N}_{2} \mathrm{O}$.

The fairly constant $\mathrm{N}_{2} \mathrm{O}$ production rates throughout the WD incubations are in accordance with the theory of Van der Lee et al. (1999), who argued that denitrification in anoxic microsites within decomposed Douglas fir needles may be responsible for $\mathrm{N}_{2} \mathrm{O}$ production in well-drained forests. They observed that this anoxic organic matter fraction of the forest floor did not significantly decrease with decreasing water content, which may explain the continuing $\mathrm{N}_{2} \mathrm{O}$ production while our litter dried out. Martikainen and De Boer (1993), on the other hand, showed that aerobic production of $\mathrm{N}_{2} \mathrm{O}$ by nitrification may as well occur in litter of our forest type, and we cannot resolve whether this mechanism or denitrification in microsites was responsible for the observed $\mathrm{N}_{2} \mathrm{O}$ production.

Similar, for the MO treatments it is not clear which of the two mechanisms accounted for the $\mathrm{N}_{2} \mathrm{O}$ production. However, we cannot think of sound reasons why $\mathrm{N}_{2} \mathrm{O}$ production rates would increase with the duration of the experiment when nitrification was the prime mechanism. Martikainen and De Boer (1993) indeed measured a constant $\mathrm{N}_{2} \mathrm{O}$ production rate in their litter, which was incubated under similar moisture conditions $(w=280 \%)$ as our litter, although it should be mentioned that they used $\mathrm{F}$ instead of $\mathrm{L}$ horizon material. When denitrification was responsible for $\mathrm{N}_{2} \mathrm{O}$ production in our experiment, $\mathrm{N}_{2} \mathrm{O}$ production conditions were in principle favorable, because of the presence of easily decomposable organic matter. Concurrent to Van der Lee (2000), we hypothesize that due to high $\mathrm{O}_{2}$ consumption, as shown by the continuously high $\mathrm{CO}_{2}$ respiration rates, over the course of the experiment anoxic conditions may have developed in water filled pores outside of litter particles. The continuous increase in $\mathrm{N}_{2} \mathrm{O}$ production can then be explained by a continuous increase in anoxic volume. 
Implications of $\mathrm{N}$ additions for $\mathrm{N}$ retention and loss at the Speuld forest

Even though our experiment comprised of 9 days only, it gives some information on possible $\mathrm{N}$ sources and sinks in fresh Douglas for litter on the longer term. Here, focus is on the WD experiments as these more closely mimic actual moisture conditions in the Speuld litter.

In the first few hours after additions, an apparent relation between $\mathrm{N}$ mineralization and amount of $\mathrm{N}$ added was found, i.e. a net $\mathrm{N}$ immobilization was observed when $\mathrm{NH}_{4}{ }^{+}$had been added to the litter. After 9 days of incubation, however, any effect of this short-term reaction of $\mathrm{N}$ mineralization to $\mathrm{N}$ addition had disappeared. Observed net $\mathrm{N}$ immobilizations, determined over the total incubation period, were relatively small and any differences between treatments were insignificant. It thus seems unlikely that immobilization is an important $\mathrm{N}$ sink in the Speuld LF1 horizon.

Even though $\mathrm{NO}_{3}^{-}$was net produced over the period of incubation, two pathways of inorganic-N loss were associated with $\mathrm{NO}_{3}{ }^{-}$. Firstly, following Dail et al. (2001), when the rapid retention of added $\mathrm{NO}_{3}{ }^{-}$directly after additions was due abiotic transformation of $\mathrm{NO}_{3}{ }^{-}$into DON, this could be a longerterm sink for $\mathrm{NO}_{3}{ }^{-}$. Secondly, even in the WD incubations, about half of the $\mathrm{NO}_{3}^{-}$net produced was transformed into $\mathrm{N}_{2} \mathrm{O}$, denoting the relative importance of denitrification in exporting $\mathrm{NO}_{3}{ }^{-}$from the LF1 horizon. The contribution of both sinks to the total $\mathrm{N}$ balance of the Speuld forest, however, remains relatively small as dry mass of the LF horizon is only $12 \%$ of the total dry mass of the forest floor (Wessel and Tietema 1995). Rough estimates demonstrate that the maximum loss of $\mathrm{NO}_{3}^{-}$via incorporation into DON or loss as $\mathrm{N}_{2} \mathrm{O}$ is about $1 \mathrm{~kg}-\mathrm{N} \mathrm{ha}^{-1} \mathrm{yr}^{-1}$ for each $\mathrm{NO}_{3}{ }^{-}$sink, respectively, which is small compared to the $31 \mathrm{~kg}-\mathrm{N} \mathrm{ha}{ }^{-1} \mathrm{yr}^{-1}$ of $\mathrm{NO}_{3}^{-}$that are leached from the soil at $90 \mathrm{~cm}$ depth.

\section{Conclusions}

Upon moisture, $\mathrm{NH}_{4}{ }^{+}$and $\mathrm{NO}_{3}{ }^{-}$additions to fresh Douglas fir litter, a series of transformations occur of which most notable are a rapid retention of added $\mathrm{NH}_{4}{ }^{+}$and $\mathrm{NO}_{3}{ }^{-}$and a sudden increase in $\mathrm{CO}_{2}$ respiration. In days following wetting, inorganic-N mineralization and $\mathrm{CO}_{2}$ respiration seem closely connected, and our results suggest that net $\mathrm{N}$ mineralization occurs only when respiration rates decrease after an initial respiration increase. Fresh Douglas fir litter has a high potential for production of $\mathrm{N}_{2} \mathrm{O}$, but this potential is exploited only under prolonged wet conditions, which do not often occur in the field. Still, dried-and-rewetted litter acts partly as a sink for $\mathrm{NO}_{3}{ }^{-}$, through rapid incorporation of added $\mathrm{NO}_{3}{ }^{-}$in the soil and gaseous loss of $\mathrm{NO}_{3}{ }^{-}$as $\mathrm{N}_{2} \mathrm{O}$.

Acknowledgements The presented work was part of a $\mathrm{PhD}$ study funded by the EU (Project EVK1-1999-00011) and the University of Amsterdam. The authors thank Joke Westerveld, Piet Wartenbergh and Ton van Wijk for carrying out the laboratory analysis. Maartje van Meeteren is thanked for valuable comments on earlier drafts of this paper.

Open Access This article is distributed under the terms of the Creative Commons Attribution Noncommercial License which permits any noncommercial use, distribution, and reproduction in any medium, provided the original author(s) and source are credited.

\section{References}

Berntson GM, Aber JD (2000) Fast nitrate immobilization in N saturated temperate forest soils. Soil Biol Biochem 32:151-156

Birch HF (1964) Mineralization of plant nitrogen following alternate wet and dry conditions. Plant Soil 24:333-339

Blackmer AM, Bremner M (1978) Inhibitory effect of nitrate on reduction of $\mathrm{N}_{2} \mathrm{O}$ to $\mathrm{N}_{2}$ by soil microorganisms. Soil Biol Biochem 10:187-191

Borken W, Matzner E (2008) Reappraisal of drying and wetting effects on $\mathrm{C}$ and $\mathrm{N}$ mineralization and fluxes in soils. Glob Change Biol 14:1-17

Borken W, Davidson EA, Savage K, Gaudinski J, Trumbore SE (2003) Drying and wetting effects on carbon dioxide release from organic horizons. Soil Sci. Soc. Am. J. 67:1888-1896

Bosveld FC, Bouten W, Noppert F, Steingröver EG, Tiktak A (1993) The ACIFORN Hydrological Programme-The water cycle of a Douglas fir forest. Technical reports TR152, KNMI, De Bilt, The Netherlands

Clein JS, Schimel JP (1994) Reduction in microbial activity in birch litter due to drying and rewetting events. Soil Biol Biochem 26:403-406

Colman BP, Fierer N, Schimel JP (2007) Abiotic nitrate incorporation in soil: is it real? Biogeochemistry 84:161-169

Colman BP, Fierer N, Schimel JP (2008) Abiotic nitrate incorporation, anaerobic microsites, and the ferrous wheel. Biogeochemistry 91:223-227 
Dail DB, Davidson EA, Chorover J (2001) Rapid abiotic transformation of nitrate in an acid forest soil. Biogeochemistry 54:131-146

Davidson EA, Chorover J, Dail DB (2008) Iron interference in the quantification of nitrate in soil extracts and its effect on the hypothesized abiotic immobilization of nitrate. Biogeochem 90:65-73

Draaijers GPJ, Erisman JW, Lövblad G, Spranger T, Vel E (1998) Quality and uncertainty aspects of forest deposition estimation using throughfall, stemflow and precipitation measurements. TNO-MEP-R98/093, TNO Institute of Environmental Sciences, Energy Research and Process Innovation, Apeldoorn, The Netherlands

FAO (2006) World reference base for soil resources 2006. A framework for international classification, correlation and communication. World soil resources reports 103, FAO, Rome, Italy, 128 pp

Fitzhugh RD, Lovett GM, Venterea RT (2003) Biotic and abiotic immobilization of ammonium, nitrite, and nitrate in soils developed under different tree species in the Catskill Mountains, New York, USA. Glob Change Biol 9:1591-1601

Green RN, Trowbridge RL, Klinka K (1993) Towards a taxonomic classification of humus forms. For Science 39:1-48

Hansen K, Draaijers GPJ, Ivens WPMF, Gundersen P, Van Leeuwen NFM (1994) Concentration variations in rain and canopy throughfall collected sequentially during individual rain events. Atmos Environ 28:3195-3205

Koopmans CJ, Tietema A, Boxman AW (1996) The fate of N15 enriched throughfall in two coniferous forest stands at different nitrogen deposition levels. Biogeochemistry 34:19-44

Kuzyakov Y, Friedel JK, Stahr K (2000) Review of mechanisms and quantification of priming effects. Soil Biol Biochem 32:1485-1498

Lund V, Goksøyr J (1980) Effects of water fluctuations on microbial biomass in soil. Microb Ecol 6:115-123

Martikainen PJ, De Boer W (1993) Nitrous-oxide production and nitrification in acidic soil from a Dutch coniferous forest. Soil Biol Biochem 25:343-347

Michel K, Matzner E (2003) Response of enzyme activities to nitrogen addition in forest floors of different $\mathrm{C}$-to-N ratios. Biol Fert Soil 38:102-109

Muhr J, Goldberg SD, Borken W, Gebauer G (2008) Repeated drying-wetting cycles and their effects on the emission of $\mathrm{CO}_{2}, \mathrm{~N}_{2} \mathrm{O}$, NO and $\mathrm{CH}_{4}$ in a forest soil. J Plant Nutr Soil Sci 171:719-728
Pulleman M, Tietema A (1999) Microbial C and N transformations during drying and rewetting of coniferous forest floor material. Soil Biol Biochem 31:275-285

Raat KJ, Draaijers GPJ, Schaap MG, Tietema A, Verstraten JM (2002) Spatial variability of throughfall water and chemistry and forest floor water content in a Douglas fir forest stand. Hydrol Earth Syst Sci 6:363-374

Schaap MG, Bouten W, Verstraten JM (1997) Forest floor water content dynamics in a Douglas fir stand. J Hydrol 201:367-383

Schimel JP, Weintraub MN (2003) The implications of exoenzyme activity on microbial carbon and nitrogen limitation in soil: a theoretical model. Soil Biol Biochem 35:549-563

Tietema A (1993) Mass-loss and nitrogen dynamics in decomposing acid forest litter in the Netherlands at increased nitrogen deposition. Biogeochemistry 20:45-62

Tietema A, Wessel WW (1992) Gross nitrogen transformations in the organic layer of acid forest ecosystems subjected to increased atmospheric nitrogen input. Soil Biol Biochem 24:943-950

Tietema A, Riemer L, Verstraten JM, Van der Maas MP, Van Wijk AJ, Van Voorthuyzen I (1993) Nitrogen cycling in acid forest soils subject to increased atmospheric nitrogen input. For Ecol Manage 57:29-44

Tiktak A, Bouten W (1994) Soil water dynamics and long-term water balances of a Douglas fir stand in the Netherlands. J Hydrol 156:265-283

Van der Lee GEM (2000) Anoxic conditions in a Douglas fir litter layer. Implications for denitrification. PhD Thesis, Universiteit van Amsterdam, Amsterdam, The Netherlands, $133 \mathrm{pp}$

Van Breemen N, Verstraten JM (1991) Thematic report on soil acidification and nitrogen cycling. In: Heij G, Schneider T (eds) Acidification research in the Netherlands. Studies in environmental science. Elsevier, Amsterdam, pp 289-352

Van der Lee GEM, De Winder B, Bouten W, Tietema A (1999) Anoxic microsites in Douglas fir litter. Soil Biol Biochem 31:1295-1301

Wessel WW, Tietema A (1995) Metal distribution across different pools in the organic layer of a forest under acid deposition and its consequences for the metal dynamics. Plant Soil 171:341-350

Wolf I, Brumme R (2003) Dinitrogen and nitrous oxide formation in beech forest floor and mineral soils. Soil Sci Soc Am J 67:1862-1868 